\title{
COMMENTS
}

\section{LEARNED TREATISES AS DIRECT EVIDENCE: THE ALABAMA EXPERIENCE*}

A majority of American jurisdictions refuse to permit the use of learned treatises as direct evidence, reasoning that to do so would violate the rule against hearsay evidence. However, many commentators have contended that, in adopting such a position, these courts have failed to consider the underlying purposes of the hearsay rule. Alabama, which has permitted the introduction of treatises as direct evidence, affords a useful contrast for testing both the rationale of the majority rule and the criticisms of it. It has been the goal of this comment to evaluate the present majority view against the Alabama experience. On the basis of the responses of Alabama attorneys, the conclusion is that the admission of learned treatises as direct evidence would be a desirable modificacation of the present rules of evidence.

I

N NEARLY all American jurisdictions the hearsay rule denies admission of learned treatises in evidence as proof of the truth of statements contained therein. ${ }^{1}$ This near unanimity has not gone unchallenged, however, as the rule has been disparaged by virtually all commentators who have treated the subject, ${ }^{2}$ and both the Model

- The Dukr Law Journal would like to express its appreciation to the officers of the Alabama State Bar Association for the invaluable assistance which they rendered during the early stages of this project.

1 E.g., Union Pac. Ry. v. Yates, 79 F. 584 (8th Cir. 1897); Gallagher v. Market Street Ry., 67 Cal. 13, 6 P. 869 (1885); Ruth v. Fenchel, 37 N.J. Super. 295, 117 A.2d 284 (1955), aff'd, 21 N.J. 171, 121 A.2d 373 (1956); Hallworth v. Republic Steel Corp., 153 Ohio St. 349, 91 N.E.2d 690 (1950); Eckleberry v. Kaiser Foundation N. Hosps., 226 Ore. 616, 359 P.2d 1090 (1961).

Wigmore suggests that the phrase "learned treatises" is a more accurate representation of the scope of the rule than "books of science and art" or "scientific books." Nevertheless, the controversy is pretty well limited to books on the "inexact" sciences, predominantly medicine. See 6 J. WIGMORE, EviDENCE $\$ 1690$ (3d ed. 1940) (hereinafter cited as WigmorE]. The exception has long been established in most jurisdictions as to the so-called "exact" sciences, such as mathematics. Under this exception annuity tables, mortality tables, almanacs, etc. have been admitted, despite their hearsay character. Westchester Fire Ins. Co. v. Buffalo Housewrecking \& Salvage Co., 40 F. Supp. 378 (W.D.N.Y. 1941); Butler v. Borowsky, 120 So. 2d 656 (Fla. App. 1960); Mitchel1 v. Arrowhead Freight Lines, Ltd., 117 Utah 224, 214 P.2d 620 (1950); see Note, 2 BAYLOR L. REV. 104 (1949). The theory supporting the admissibility of such publications in evidence is that they are based on unchanging data, whereas medical and other learned treatises are not.

2 See, e.g., 6 Wigmore $\$ 1690$; Note, 52 Cornell L.Q. 316 (1967); Note, 29 U. CiN. L. REv. 255 (1960); 2 U.C.L.A.L. REv. 252 (1954). 
Code of Evidence and the Uniform Rules of Evidence provide expressly that learned treatises are properly admissible. ${ }^{3}$ Furthermore, the decisional law of Alabama has constituted a long-standing exception to the majority rule. ${ }^{4}$ Evaluation of the present rule has largely been in terms of abstract argument, with both proponents and critics predicting that its alteration would have various consequences on the actual conduct of trials. ${ }^{5}$ Without denying the value and necessity of scrutinizing the rule and proposed changes against the demands of a rational trial process, it would seem that any conclusive verdict must be built on the results of empirical studies as well. As one writer correctly observed, "The final consideration is: Will the proposed [learned treatises exception] ... work? For the answer we must look to the state of Alabama where such evidence has been received ... over a long period of years." 6 In response to this need, the primary design of this comment will be to evaluate the learned treatises exception in light of its actual implementation in Alabama practice. To obtain the necessary data a questionnaire was sent to nearly all trial attorneys in that state, ${ }^{7}$ and their responses form the basis for the principal observations and conclusions made herein. Emphasis

${ }^{3}$ Uniform Rule of Evidence 63 (31), adapted from the Model Code of Evidence $\$ 529$ (1942): "Learned Treatises. A published treatise, periodical or pamphlet on a sub. ject of history, science or art [is admissible] to prove the truth of a matter stated therein if the judge takes judicial notice, or a witness expert in the subject testifies, that the treatise, periodical or pamphlet is a reliable authority in the subject."

"Stoudenmeier v. Williamson, 29 Ala. 558 (1857), is the first reported case in which the exception was recognized in Alabama. See the discussion of the Alabama position in text accompanying notes 8-22 infra.

- For example, those opposed to the reception of medical treatises as evidence have charged, among other things, that such materials are characterized by instability, would only confuse the jury, and are unreliable because they lack the sanction of an oath. See 6 WIGMORE $\$ 1690$. Proponents, on the other hand, have argued that the adversary system would remedy any such defects and that significant cost savings would result from the availability of medical books for use as evidence. Id. $\$ 1691$.

- Dana, $A$ Code of Evidence for Wisconsin, Admission of Learned Treatises in Evidence, 1945 WIs. L. REv. 455, 461.

'Questionnaires were mailed to approximately ninety-one percent of Alabama's attorneys in an effort to canvass thoroughly the state's trial bar (no list of the latter being available). One hundred and eighteen questionnaires were returned. See note 84 infra. Of this number, twenty-seven were disallowed because the questionee indicated he lacked any experience in utilizing the learned treatises exception, and five blank questionnaries were discarded, leaving eighty-six "qualified questionnaries." In computing the total responses on a particular question, any questionnaire whose answer was internally inconsistent was not counted. The writers of this comment recognize that the derivation of viable generalizations from surveys of this kind is a very delicate task and that the conclusions reached must be accepted cautiously, if for no other reason than that the reliability of aggregate answers might be distorted by some unknown variable. Sce Appendix for reprint of the questionnaire. 
throughout is on the use of medical books, since they are the treatises most often encountered in the cases and, presumably, in day-to-day courtroom experience.

\section{Current State of the Law}

\section{The Alabama position}

The minority Alabama rule dates from the early case of Stoudenmeier $v$. Williamson, ${ }^{8}$ where the state supreme court, in reviewing a civil action, upheld the admission in evidence of a medical treatise on venereal disease. Although aware of the dearth of authority on the issue, the court permitted the jury to consider such evidence since the admissible opinions of physicians as to medical matters were themselves founded substantially on the published writings of other medical experts. To accord the former evidentiary respectability while denying the same status to the latter would be to impose an unjustifiable limitation, depriving the jury of a valued source of knowledge. ${ }^{\theta}$ As a precondition to admission, the court posited the requirement that the party seeking to introduce medical books authenticate them as "standard works with that profession." In addition, the court stated that any technical or confusing portions would have to be clarified for the jury.10

Sixty-six years after the Williamson decision, the Alabama legislature enacted a statute declaring that "books of science or art" were, "when made by persons indifferent between the parties, ... prima facie evidence of facts of general notoriety and interest."11 This provision has been interpreted by the state supreme court as statutory approval, ${ }^{12}$ though not a comprehensive statement, ${ }^{13}$ of the Williamson hearsay exception. However, the operative details of this judi-

${ }^{8} 29$ Ala. 558 (1857).

Id. at 567. The court, in addition, analogized the admission of medical treatises to aid the jury in resolving factual disputes to the long-sanctioned reliance by the judge on standard legal commentaries to settle questions of law. Id. at 568.

${ }^{10}$ Id. at 567 .

12 ALA. Cone tit. 7, $\$ 413$ (1960).

12 City of Dothan v. Hardy, 237 Ala. 603,188 So. 264 (1939).

1s Statutes identical to the Alabama provision are on the books in seven other states. See note 29 infra. Alabama is the only jurisdiction, however, which has construed this provision to authorize the introduction of medical texts as independent evidence. The soundness of this interpretation is questionable since the provision is, on its face, limited to "facts of general notoriety and interest," while the compass of facts provable by treatise evidence under the Williamson rule is much broader, encompassing technical and obscure matter. See 6 WIGMORE $\$ 1693$; note 30 infra. 
cially-created rule of evidence have been developed by case law. Moreover, although the focus in Williamson was confined to medical books, the compass of the rule has been extended more broadly to include other scientific treatises, ${ }^{14}$ such as a national safety code handbook reporting findings regarding the "science of electricity."16 The use of scientific periodicals under the rule has not received explicit sanction by Alabama's appellate courts, even though it would appear that such materials would be admissible if properly authenticated. ${ }^{16}$ The fact that an author has merely reported the findings of others will not sustain a hearsay objection, since the author's demonstrated standing as an authority permits the use of his own statements and those of others which he has chosen to adopt and incorporate as his own. ${ }^{17}$ In addition to the authentication requirement, ${ }^{18}$ the

24 Police \& Firemen's Ins. Ass'n v. Mullins, 260 Ala. 173, 69 So. 2d 261 (1953) (Public Health Service Bulletin dealing with carbon monoxide admitted); City of Dothan v. Hardy, 237 Ala. 603, 188 So. 264 (1939) (U.S. Bureau of Standards handbook on electrical wiring); Merkle v. State, 37 Ala. 139 (1861) (textbook concerning fermented liquors).

${ }^{15}$ City of Dothan v. Hardy, 237 Ala. 603, 188 So. 264 (1939); cf. Cook v. State, 110 Ala. 40, 20 So. 360 (1895); Dantzler v. De Bardeleben \& Iron Co., 101 Ala. 309, 14 So. 10 (1893). In Adler v. State, 55 Ala. 16 (1876), reference to standard dictionaries was approved as an aid to statutory interpretation. Other jurisdictions have similarly permitted evidentiary use of dictionary definitions though eschewing the learned treatise rule. See 6 Wrgmore $\$ 1699$. Such a practice clearly involves acceptance of out-ofcourt "testimony" or hearsay.

When the mental competency or sanity of a party is in issue, the Alabama courts have admitted in evidence materials from the field of psychiatry, which, though considered a branch of medicine, is less stable than other branches of medical science. See Batson v. Batson, 217 Ala. 450, 117 So. 10 (1928); Anderson v. State, 209 Ala. 36, 95 So. 171 (1922); Russell v. State, 201 Ala. 572, 78 So. 916 (1918); Bale v. States, 63 Ala. 30 (1879).

${ }^{18}$ An article from the Southern Medical Association Journal was held correctly ex. cluded from evidence on the ground of insufficient authentication: "there was no imprimatur of an [expert] ... to the effect that the writing was of a substantially recognized theory such as might be found in a standard medical book." Wiggins v. State, 39 Ala. App. 433, 440, 104 So. 2d 560, 566 (1958). Two years earlier, the Fifth Circuit held that the exclusion of an article from the Journal of the American Medical Association by the federal trial judge sitting in the Northern District of Alabama was not prejudicial error in view of the testimony as a whole, commenting that this precise issue had not yet been determined by Alabama courts. Uhl v. Echols Transfer Co., 238 F.2d 760 (5th Cir. 1956). Despite these adverse holdings, responses to the questionnaires establish that medical journals have been and are being admitted by the state's trial judges.

${ }^{12}$ Blakeney v. Alabama Power Co., 222 Ala. 394, 133 So. 16 (1931).

${ }^{18}$ See Wiggins v. State, 39 Ala. App. 433, 104 So. 2d 560, cert. denied, 267 Ala. 701, 104 So. 2d 567 (1958); Franklin v. State, 29 Ala. App. 306, 197 So. 55, cert. denied, 240 Ala. 57, 197 So. 58 (1940); cf. Smarr v. State, 260 Ala. 30, 68 So. $2 d 6$ (1953). Moreover, the author must be shown to be an expert as to the narrow topic dealt with in the excerpt introduced. Timothy v. State, 130 Ala. 68, 30 So. 339 (1900). 
ordinary bounds of relevancy imposed on all types of evidence must be respected by the party proffering textual materials. ${ }^{19}$ Finally, case precedent establishes that learned treatise evidence may be offered in either criminal $^{20}$ or civil actions, ${ }^{21}$ the latter including medical malpractice suits. ${ }^{22}$

\section{Other departures from the general rule}

Wisconsin recently joined Alabama's minority position by judicially adopting for prospective application a rule permitting the admission of authoritative learned treatises. ${ }^{23}$ An official court rule in a third state, New Jersey, allows an expert witness to read passages from learned treatises after prior notice has been given. ${ }^{24}$ Moreover, while other courts have been uniformly hostile to the evidentiary use of learned treatises, ${ }^{25}$ inroads on the general rule have been made by legislative enactments in several states. Thus in Massachusetts ${ }^{26}$ and

${ }^{20}$ Occidental Life Ins. Co. v. Nichols, 266 Ala. 521, 97 So. 2d 879 (1957); Watkins v. Potts, 219 Ala. 427, 122 So. 416 (1929); Bradley v. Williams, 20 Ala. App. 308, 101 So. 808 (1924); cf. Gorman-Gammil Drug Co. v. Watkins, 185 Ala. 653, 64 So. 350 (1914). A general objection of irrelevancy will not suffice where parts of a book offered in evidence are relevant and parts are not. Bradley v. Williams, supra.

${ }^{20}$ Lambert v. State, 234 Ala. 155, 174 So. 298 (1937); Anderson v. State, 209 Ala. 36, 95 So. 171 (1922); Russell v. State, 201 Ala. 572, 78 So. 916 (1918); Oakley v. State, 135 Ala. 29, 33 So. 693 (1902); Timothy v. State, 130 Ala. 68, 30 So. 339 (1900); Bales v. State, 63 Ala. 30 (1879); Merkle v. State, 37 Ala. 139 (1861); Wiggins v. State, 39 Ala. App. 433,104 So. 2d 560, cert. denied, 267 Ala. 701, 104 So. 2d 567 (1958); Franklin v. State, 29 Ala. App. 306, 197 So. 55, cert. denied, 240 Ala. 57, 197 So. 58 (1940); cf. Smarr v. State, 260 Ala. 30,68 So. 2 d 6 (1953).

${ }^{22}$ Uhl v. Echols Transfer Co., 238 F.2d 760 (5th Cir. 1956); Occidental Life Ins. Co. v. Nichols, 266 Ala. 521, 97 So. 2d 879 (1957); Police \& Firemen's Ins. Ass'n v. Mullins, 260 Ala. 173, 69 So. 2d 261 (1953); City of Dothan v. Hardy, 237 Ala. 603, 188 So. 264 (1939); Blakeney v. Alabama Power Co., 222 Ala. 394, 133 So. 16 (1931); Watkins v. Potts, 219 Ala. 427,122 So. 416 (1929); Batson v. Batson, 217 Ala. 450,117 So. 10 (1928); Gorman-Gammil Drug Co. v. Watkins, 185 Ala. 653, 64 So. 350 (1914); Birmingham Ry. Light \& Power Co. v. Moor, 148 Ala. 115, 42 So. 1024 (1906); Stoudenmeier v. Williamson, 29 Ala. 558 (1857); Bradley v. Williams, 20 Ala. App. 308, 101 So. 808 (1924).

${ }^{22}$ Carraway v. Graham, 218 Ala. 453, 118 So. 807 (1928); Barfield v. South Highlands Infirmary, 191 Ala. 553, 68 So. 30 (1915).

${ }^{2}$ Lewandowski v. Preferred Risk Mutual Life Ins. Co., 33 Wis. 2d 69, 146 N.W.2d 505 (1966). More precisely the court appears to have adopted Rule $63(31)$ of the Uniform Rules of Evidence. Id. at 76, 146 N.W.2d at 509 .

"N.J. Rules of Evidence 63 (31), codified with N.J. Stat. ANN. § 2A: 84A-32 (Supp. 1966). See also note 58 infra and accompanying text.

${ }^{25}$ See note 1 supra.

20 MAss. ANN. LAw̌s ch. 233, §79C (Supp. 1966): "Statements of fact or opinion on a subject of science or art, contained in a published treatise, periodical, book or pamphlet shall, insofar as the court shall find that the said statements are relevant and that the writer of the said statements is recognized in his profession or calling as an expert of the subject, be admissible in actions of contract or tort for malpractice, 
Nevada, ${ }^{27}$ books and treatises written by acknowledged experts are admissible in medical malpractice actions as opinion evidence or to prove statements contained therein. South Carolina has long had a statute making medical or scientific works competent evidence in all cases involving a question of sanity or poisoning, or "any article destructive to life." 28 In a number of states, books of science and art are treated as prima facie evidence of facts of general notoriety and interest. ${ }^{28}$ In none of these jurisdictions, however, have medical books been held to qualify under the "general interest" statutory standard..$^{30}$ However, sundry types of written materials, such as legal treatises, scientific and mathematical tables, dictionaries, and works of general literature and history, are commonly received in evidence for certain purposes in these states. ${ }^{31}$ Arguably, therefore,

error or mistake against physicians, suregons, dentists, optometrists, hospitals, and sanitoria, as evidence tending to prove said facts or as opinion evidence; providing, however, that the party intending to offer as evidence any such statements shall, not less than thirty days before the trial of the action give the adverse party or his attorney notice of such intention, stating the name of the writer of the statements, the title of the treatise, periodical, book or pamphlet in which they are contained, the date of publication of the same, the name of the publisher of the same, and wherever possible or practicable the page or pages of the same on which the said statements appcar." For a case applying this statute see Thomas v. Ellis, 329 Mass. 93, 106 N.E.2d 687 (1952).

${ }^{27}$ NEv. REv. Stat. $\$ 51.040$ (1965). The Nevada statute is nearly identical in wording to its Massachusetts analogue, except that Nevada requires only three days advance notice of tille and author of the text to be offered. For a criticism of both these statutes see Seidelson, Medical Malpractice Cases and Reluctant Expert, 16 Catholic U.L. REv. 158, 169 (1966).

${ }^{28}$ S.C. CODE ANN. \$26-142 (1962).

${ }^{29}$ Cal. Evid. Code $\S 1341$ (West 1966); Idaho Code ANN. \$9-402 (1948); Iowa Code ANN. \$622.23 (1946); MONT. Rev. CODE ANN. \$93-1101.8 (1947); NEB. REv. StAT. \$25. 1218 (1964); ORE. Rev. STAT. $\$ 41.670$ (1965); UTAH CoDe ANN. \$78-25-6 (1953). Typical of all these statutes is that of Idaho: "Historical works, books of science or art, and published maps or charts, when made by persons indifferent between the parties, are prima facic evidence of facts of general notoriety and interest." Alabama has an identical statute. ALA. CoDE tit. 7, $\$ 413$ (1958).

${ }^{30}$ Note, 46 Iowa L. REv. 463 (1961). Invariably under these statutes, medical books are not deemed to contain matters of "general notoriety and interest." A classic cxplanation is given in Gallagher v. Market St. Ry., 67 Cal. 13, 6 P. 869 (1885): "What are 'facts of general notoriety and interest?' We think the terms stand for facts of a public nature, either at home or abroad, not existing in the memory of men as contradistinguished from facts of a private nature existing within the knowledge of living men, and as to which they may be examined as witnesses .... Such facts include the meaning of words and allusions which may be proved by ordinary dictionaries and authenticated books of general literary history, and facts in the exact sciences founded upon conclusion reached from certain and constant data by processes too intricate to be elucidated by witnesses when on cxamination." Id. at 15, 6 P. at 871 (emphasis in original); see Van Skike v. Potter, 53 Neb. 28, 73 N.W. 295 (1897).

32 See 1, 3 B. JONES, EvideNCE $\S \S 145,621,633$ (5th ed. 1958); 6 WiGMore $\$ \S 1697-99$; Note, 2 Baylor L. REv. 104 (1949). 
reception of such hearsay writings constitutes a partial, implied recognition of the validity of the principle underlying the learned treatises exception. ${ }^{32}$

\section{Learned treatises in cross-examination}

Although the rule as to inadmissibility is well settled when the treatise is offered as direct, substantive evidence, ${ }^{33}$ the limits on use of such materials on cross-examination to impeach or discredit a witness are not well defined..$^{3}$ Under the more restrictive rule, medical books may not be used to impeach or discredit an expert witness unless the witness has based his opinion in whole or in part on the authorities. $^{35}$ On the other hand, a more liberal rule allows crossexamination with reference to standard authorities, irrespective of whether the witness has relied on them, in order to test the knowledge of the alleged expert. ${ }^{36}$ Under both rules, however, reference to the learned treatises is allowed only for purposes of impeaching or establishing the competency of a witness and not for the purpose of employing the statements as evidence. ${ }^{37}$ While the theoretical distinc-

as See 6 WigMore $\S 1696$.

ss Appellate courts following the majority rule have even reprimanded trial judges for making substantive reference to medical books in their opinions. Barks v. Herzberg, 206 A.2d 507 (Del. Ch. 1965) (harmless error).

st The rule against direct admission of medical books seems also to comprehend the situation where medical books are used in direct examination of an expert witness. E.g., Commonwealth v. Sturtivant, 117 Mass. 122, 139 (1875); Zoldoske v. State, 82 Wis. $580,605,52$ N.W. 778, 786 (1892): "Text-books or scientific works cannot be read in evidence to the jury, and the rule cannot be defeated or evaded by getting their con. tents before the jury by having a witness testify to what they contain."

${ }^{85}$ It is generally accepted that if a witness has based his opinion at least partially on written authorities, it is proper to cross-examine him with respect to such authorities. Darling v. Charleston Community Memorial Hosp., 50 I11. App. 2d 253, 330, 200 N.E.2d 149, 187 (1964), cert. denied, 383 U.S. 946 (1966). In some cases the cross-examination must be limited to the exact authorities relied on by the witness. C. McCormIck, Evidence 620, n.3 (1954). Conversely, in these jurisdictions, if the witness in no way purports to base his testimony on authoritative publications, he cannot be crossexamined with reference to any standard authorities in the field. Gluckstein $v$. Lipsett, 93 Cal. App. 2d 391, 209 P.2d 98 (1949); Mann v. Blair, 195 Ill. App. 254 (1915); State v. Blackburn, 136 Iowa 743, 114 N.W. 531 (1908).

${ }^{30}$ Reilly v. Pinkus, 338 U.S. 269 (1949) (when witness based testimony in part on medical books, it was error to refuse cross-examination from other medical books); Ruud v. Hendrickson, 176 Minn. 138, 222 N.W. 904 (1929) (excerpts may be read on cross-examination from authorities in order to test knowledge and competency of expert witness); Laird v. Boston \& M.R.R., 80 N.H. 377, 117 A. 591 (1922); Kern v. Pullen, 138 Ore. 222, 6 P.2d 224 (1931), overruled on other gnounds, 167 Ore. 439, 450, 117 P.2d 825, 829 (1941).

${ }^{87}$ Ruth v. Fenchel, 37 N.J. Super. 295, 117 A.2d 284 (1955), aff'd, 21 N.J. 171, 121 A.2d 373 (1956). Perhaps more realistic is a dissenting view: "In both instances [direct and cross-examination], the treatises are offered for the truth of what they contain 
tion is clear, practical applications of treatises in cross-examination render the purported limitations meaningless. For example, an attorney may ask a witness on cross-examination if a book is authoritative in the profession; upon receiving an affirmative reply, he then reads from the book and asks the witness if he is familiar with that passage. ${ }^{38}$ Under the guise of testing the witness' knowledge, the desired textual material is thus presented to the jury.

\section{The Alabama Exception in Practice}

\section{Text vs. witness}

For purposes of analysis, the Alabama practitioner may be said to have, in any trial involving medical issues, an option of employing either a live expert witness or a medical treatise to present the desired medical facts. A number of factors bear on this initial, tactical choice. Perhaps the most elemental is the relative intrinsic persuasiveness of the two kinds of evidence. Given a rough equivalence in the respective authority of the witness and the author, it was the opinion of almost all the attorneys questioned that the expert on the stand enjoys a decided superiority over the treatise. ${ }^{39}$ The reasons given varied. The mere physical presence of the witness serves to focus the attention of the jury on the evidence being presented in a more dramatic way than does a textual reading. The personal appearance of the expert also permits the jurors to evaluate his sincerity, positiveness, and seeming competence, as well as to observe other qualitative nuances of bearing and demeanor, a potent factor

and, in both instances the question involves whether the treatises have enough trustworthiness to justify an exception to the hearsay rule." Note, $29 \mathrm{U}$. CiN. L. REv. 255, 262 (1960).

${ }^{88}$ It is precisely to avoid the presentation of learned treatise evidence in this manner that the general rule against their admission on direct examination has been adopted in the same jurisdictions. See note 34 supra. "[T] he plaintiffs were permitted ... in the examination in chief of medical witnesses called by themselves to read extracts . . . and then to ask the witnesses if what was so read corresponded with their own judgment .... But it is not permissible in this manner to evade the general rule of evidence. ..." Lilley v. Parkinson, 91 Cal. 655, 656, 27 P. 1091 (1891).

${ }^{80}$ Of those Alabama attorneys who had offered learned treatises into evidence, thirty-eight thought that a jury would accept the opinion of a live expert witness over a conflicting text statement, one answered to the converse, and thirty-one indicated that the jury would accept one or the other rather unpredictably. In another question in which it was assumed that the witness and the book were of substantially equal merit and authority, presentation of evidence via a live expert witness was deemed intrinsically more effective "in nearly all instances" by fifty-one practitioners, "in most instances" by twenty-two, and "in some instances" by two. No one marked the "in few instances" alternative. 
which may increase, or occasionally detract from, the jurors' respect for the evidence submitted. However, in a case where the bias of a medical expert may effectively be brought out on cross-examination by the opposing counsel, the impartiality of the text writer ${ }^{40}$ serves to offset the "natural" effectiveness of live testimony. Almost no mention was made by the responding attorneys, however, of this theoretically counterbalancing force.

Implicit in the general advantage of having the medical expert before the court is the fact that he, in a sense, has the "last word" in any disagreement with a text author. Thus, by "clarifying" his position and "distinguishing" or "qualifying" that of a text writer, the medical witness can explain away or reconcile any apparent inconsistencies between his view and that of the treatise. Furthermore, because of the flexibility of live testimony obtained through direct examination, the witness gives the attorney greater latitude for emphasis and repetition. Moreover, a properly prepared medical expert can, by explaining medical terminology and utilizing lay idiom, communicate more effectively with the average juror, who is likely to be confused by a technical treatise excerpt. Of course, judicious selection of excerpts would alleviate this problem. However, in some cases this solution is impeded by the unavailability of a text statement relating directly to the particular medical issue at hand or the absence of any single source adequately covering the issue, necessitating resort to several texts with attendant inconvenience and confusion.

As a further factor relevant to the choice of witness or treatise, any marked difference in authoritativeness between the text writer and the physician-witness will be crucial. The jurors' greater familiarity with the physician or at least with his reputation, a common occurrence in small counties, was mentioned as having a decisive impact. The fact that the medical witness has personally examined the person whose health is in dispute will naturally add

10 The fact that a medical text is written by a party independent of the lawsuit and with no view to litigation has been advanced to demonstrate the special reliability of this kind of evidence. See 6 WIGMORE $\$ 1692$. This intrinsic disinterestedness of a medical author and his knowledge of the critical scrutiny which will be given to his writing by professional colleagues arguably vitiates the objection that text writers are not subjected to the solemnizing requirement of an oath. See Note, 52 CorNell L.Q. 316 (1967). One commentator has argued that these factors make less urgent the need for cross-examination when treatise evidence is admitted. Dana, supra note 6, at 459-60. Contra, Note, 52 CoRNELL L.Q. 316, 317 (1967). 
weight to his testimony. Other variations in the relative authoritativeness factor may be shown: a doctor with specialized training and experience in the area of interest opposed to a "general" medical textbook; a written work of wide repute and unassailable merit, such as Gray's Anatomy, opposed to a young or apparently inexperienced or unsure doctor; a qualified physician opposed to an article published in some lesser-known medical journal or periodical.

The result of this felt superiority of the expert witness over the treatise for the presentation of medical evidence is that the practitioner will seldom, if ever, rely solely on the latter. In most instances it is necessary to have a doctor appear to authenticate the text sought to be used, though other means of authentication are available.41 Therefore, because of strategic purposes and operative requirements, introduction of text material will usually be accompanied by testimony of an expert witness. Whether the expert's role is viewed as one of authenticating and interpreting the treatise or as one of proffering the principal evidence by testimony is a distinction lacking functional significance. ${ }^{42}$

\section{Factors determining extent of use of treatises}

Disparities in the extent of reliance on witnesses and textual presentations reflect the influence of a number of elements other than the implicit features of the two kinds of evidence. The lawyer's method of presentation can expand the efficacy of either. The questionnaire responses indicated that some consideration is given to the contextual dimensions ${ }^{43}$ of the case itself. While live testimony is

\$1 Counsel may avoid the necessity of procuring his own expert to testify by having the opposing party's medical expert admit on cross-examination to the quality and repute of a text to be offered as direct evidence. While such a hostile witness may be uncooperative in placing any stamp of authority on the text, he will also be hesitant to appear unread or ill-equipped by denying familiarity with a standard medical work. Stipulation of the parties, judicial notice, and testimony of a medical librarian are additional, feasible routes to authentication not requiring the in-court testimony of a physician.

\$2 From the comments made on several of the questions it is clear, however, that most Alabama attorneys using text evidence regard it as supplementary material which does assume considerable importance when primary, testimonial evidence is unavailable.

${ }^{3}$ The questionee was asked to assess the impact of the following circumstances on his use of a live witness and/or a medical treatise: the difficulty of the medical issue; the identity of the finder of fact, i.e., judge or jury; the sex and/or race of his client (or of the opposing client); the type of court, i.e., state or federal; the nature of the case, i.e., criminal or civil, medical malpractice, etc.; and the side of the case he represented, i.e., plaintiff or defendant, prosecution or defense. 
clearly preferred by counsel in a jury trial, some practitioners are more inclined to rely on treatise evidence where a judge is fact-finder. The difficulty of the medical issue involved was identified as apposite, but it was not clear which type of evidence a complex medical issue would encourage.

Most prominent of these contextual dimensions is the nature of the case, resort to text evidence being more recurrent in medical malpractice suits than in other kinds of actions. The explanation of this preference is perhaps obvious, in view of the well-known reluctance of doctors to testify against another member of their profession who is charged with malpractice. Thus, in small rural areas the needed expert testimony may almost be nonexistent. A medical treatise may then be the only feasible source of evidence available to the plaintiff. With it he can satisfy the Alabama scintilla of evidence rule ${ }^{44}$ and reach the jury with the negligence issue, thereby avoiding an affirmative charge for the other party. Even beyond this, however, the possession and use of a respected medical treatise assures a greater degree of truthfulness and objectivity on the part of the defendant doctor or another physician testifying in his behalf, according to a number of the attorneys questioned. This protection probably derives more immediately from use of the treatise in crossexamination, but even as independent evidence the treatise is a valuable tool for meeting the recognized advantage of defendants in this type of case. The greater importance of learned treatises to the trial of medical malpractice suits was demonstrated by the responses to the question querying the impact of abolition of the rule. Approximately two-thirds of the lawyers questioned agreed that abolition would considerably alter day-to-day practice in trying medical malpractice cases, whereas most felt that criminal practice would be affected only to a small degree. Similarly, a heavy majority expressed the latter opinion as to personal injury cases in general..$^{45}$

"See, e.g., Ball v. National Life \& Accident Ins. Co., 270 Ala. 265, 118 So. 2d 724 (1960).

45 The question and numerical distribution of responses are as follows: To abolish the learned treatise rule in Alabama would alter the day-to-day practice in Alabama:

criminal cases

personal injury cases

medical malpractice cases drastically considerably

5

13

25

4

16

17 to a small degree

31

37

18 not at all

12

8 7 
As a further factor, any expense and/or inconvenience involved in the production and use of evidence will enter into the practitioner's planning of his case. One argument advanced to support the learned treatises exception is that savings accrue to a party when the availability of inexpensive treatise evidence makes unnecessary the costly procurement of one or more expert medical witnesses. Actually the burden on the lawyer's time and the litigant's pocketbook should be roughly the same for both kinds of evidence, since authentication of treatise material is typically accomplished by testimony of a physician. ${ }^{46}$ This practice and the observed reluctance of counsel to rely on text evidence without the support of live expert testimony compel the conclusion that the cost and convenience factors are not weighted in favor of the treatise as is often supposed. In fact, in addressing themselves to this issue, almost as many Alabama attorneys responded affirmatively as negatively to the statement that it was generally more troublesome and/or expensive to produce a witness to authenticate a medical treatise than to procure an expert witness to prove the same facts by oral testimony. ${ }^{47}$ The reasons for this surprising response are not clear. Despite this reported experience, however, it is perhaps worth noting that there remains a potential economy, to the extent that counsel can or will avail himself of a mode of authentication not requiring the courtroom presence of a physician. ${ }^{48}$

The extent of reliance on treatise evidence might further be influenced by the difficulty accompanying introduction of such material. The authentication hurdle is most often surpassed by testimony of the party's physician on direct examination. A second, frequently employed method is to have the opponent's physician admit to the authority of the work on cross-examination. Since use of a treatise for impeachment purposes is customarily prefaced by such an admission, it is difficult to assess the extent to which authentication by cross-examination relates to the employment of such material as

\footnotetext{
${ }^{4}$ But see note 41 supra.

${ }^{17}$ Twenty lawyers answered that it was more troublesome and/or expensive to use an authenticating witness, and twenty-four indicated that less trouble and/or expense was involved in this use. Although the question, as posed, did not include a "no difference" alternative answer, twelve lawyers wrote in comments to that effect, noting that the same medical witness is almost always used by them for both purposes.

4 See note 41 supra.
} 
independent evidence. Pre-trial stipulation of the parties as to the standing of a text within the medical profession would obviate the need for in-court authentication, but this practice is apparently not widespread in Alabama. Similarly, the testimony of an expert witness would not be needed and a trial expense averted if judicial notice were liberally taken of the authenticity of standard works.90 Except in isolated instances, ${ }^{50}$ Alabama judges have not permitted this "short-cut."

Nevertheless, the cumulative experience of the attorneys responding to the questionnaire indicates that only a very small percentage of the proffers of text evidence have met with rejection by the trial courts. $^{51}$ The principal ground for exclusion has been the technical defect of insufficient authentication. The more general evidentiary objections of hearsay and irrelevancy have been urged with success only infrequently. That the former objection is sustained at all is curious in light of the fact that the Williamson rule operates precisely as an exception to the hearsay doctrine; however, the explanation

\footnotetext{
${ }^{40}$ As an example of other modes of authentication, judicial notice of the authority of a proffered text might be taken on an extension of the "facts of general notoriety" theory, i.e., the work is widely or commonly recognized as standard by those in the medical profession. Professor McCormick suggests that the law has not yet extended this "common knowledge concept" to the body of knowledge common only to those in a given field, although a few courts have moved in this direction. C. McCormick, EvIDENCE $\$ 324$ \& nn.7-8 (1954). Facts capable of ready and accurate verification or demonstration-including established propositions in the professional and scientific disciplines, C. McCormick, supra at \$325. See generally Comment, 36 Mich. L. REv. 610 (1938)-are generally accorded judicial notice, and a text's authoritativeness might be thought to fall within this classification. Or, the rule by which the genuineness of certain official documents, or the authenticity and reliability of sources containing economic and social data relied upon by a legislature in enacting controversial legislation, are given judicial notice might be applied analogously to establish the authority of medical texts introduced. In so doing the judge would not be guilty of usurping the jury prerogative of deciding questions of fact since the issue of "authority" is one of admissibility of evidence over which the judge has traditional responsibility. The provision in the Uniform Rules of Evidence making learned treatises admissible permit the judge to take "judicial notice ... that the treatise, periodical or pamphlet is a reliable authority in the subject." UNIFORM RULE OF EVIDENCE 63 (31). Opposed to this conferral of judicial notice would be the persuasive argument that a judge is not knowledgeable as to the quality of medical and scientific literature, and his only real source of such knowledge is expert opinion which should, for the protection of the other party in the case, be given in court.

${ }^{50}$ Only Gray's Anatomy and the National Electric Safety Code were specifically listed as medical-scientific materials which have, on occasion, been admitted without formal authentication. Several attorneys declared that treatises are not properly subject to judicial notice under Alabama rules of practice.

B1 By rough estimate based on the data supplied by the responding attorneys, less than one percent of medical texts submitted as evidence have been excluded.
} 
probably lies in unfamiliarity with the rule by the judiciary and the bar alike in some areas. The great bulk of attorneys questioned signified that admissibility does not depend on whether the plaintiff or the defendant seeks it, in either criminal or civil (including medical malpractice) cases. ${ }^{52}$

The type of treatise material and the subject matter may affect the emphasis which the trial practitioner places on this genus of evidence. As to the latter factor, two-thirds of the attorneys questioned reported that texts of psychiatry are not given weight equal to that accorded other medical texts by juries. Pamphlets, periodicals, and other like written materials are presumably admissible under the Williamson rule if the authentication and relevancy requirements can be met. ${ }^{53}$ Yet while a medical journal may be more current than a book and, therefore, possess special persuasive power as evidence, it may also embody findings or theories which are tentative and subject to modification with further research and investigation, an observation which the opposing counsel may be expected to make in his argument to the jury. Furthermore, jurors might speculate that resort to an "obscure" journal article was necessitated by the absence in more comprehensive treatises of support for counsel's urgings. In the same vein, a pamphlet or report may be less impressive to a jury than a text which is represented as being widely used and respected by doctors and medical schools. These observations suggest that practical limitations on the utility of certain kinds of treatise

52 The question was asked whether, from the attorney's observations, medical treatises were more likely to be admitted when offered by one side or the other in any of the specified kinds of cases. The responses are tabulated below:

$\begin{array}{lccc} & \begin{array}{c}\text { plaintiff or } \\ \text { prosecution }\end{array} & \begin{array}{c}\text { defendant } \\ \text { criminal }\end{array} & \begin{array}{c}\text { no } \\ \text { difference } \\ \text { cases }\end{array} \\ \begin{array}{l}\text { medical malpractice } \\ \text { cases }\end{array} & 5 & 14 & 31 \\ \text { other civil cases } & 7 & 8 & 44 \\ \end{array}$

${ }^{58}$ Among those periodicals and journals mentioned as having been successfully employed under the Williamson rule are: American Medical Association Journal, Clinics of North America, Journal of Industrial Medicine, New England Journal of Medicine, Mayo Clinics. But see note 16 supra. Under "other materials" were listed the National Electrical Safety Code, a newspaper article on medicine, and a variety of other sources not strictly within the learned treatises exception to the hearsay rule (encyclopedias, catalogues, building codes, hospital regulations, etc.). 
materials exist for a lawyer sensitive to the probable reception of his evidence by the jury.

\section{Procedure for trial use of treatises}

The manner of use of medical treatise evidence seems to depend largely on the preferences of the introducing lawyer, qualified in some instances by the trial judge's inherent discretionary power over details of procedure.54 Advance notice to opposing counsel of the intended introduction of specified books has not been required by trial judges in Alabama. Neither is such notice voluntarily given by the attorneys. ${ }^{55}$ An argument may be made that such advance notice would facilitate the rational operation of the rule by enabling opposing counsel to evaluate more fully the authority and accuracy of the prospective text evidence. Such an occasion for a more extended examination by the attorney or his medical advisor would discourage the offering of outdated materials or of passages out of context, and thus improve the quality of treatise evidence in general. However, almost no dissatisfaction was expressed by the questioned attorneys concerning the absence of required notice.

Presentation of the medical treatise to the jury may be accomplished by several means. The most popular approach is for the lawyer himself to read the relevant passages. This may be done by a direct recitation of the passage to the jury after the text is admitted, a recitation of the passage to the opponent's medical expert in the presence of the jury to determine if the text and the expert agree, ${ }^{56}$ and/or a reading (perhaps a second time) of the passage in the

\footnotetext{
st The matter of numerical limitations on the use of treatises at trial is discussed in text following note 79 infra.

${ }^{85}$ Both the Massachusetts and the Nevada statutes authorizing the evidentiary use of learned treatises in malpractice actions contain mandatory provisions for detailed notice to the other party in advance of trial. See notes $26-27$ supra. In New Jersey, an expert is statutorily required to give advance notice of his contemplated reading of a text excerpt during direct testimony. See note 24 supra.

so See, e.g., Barfield v. South Highlands Infirmary, 19l Ala. 553, 68 So. 30 (1915). A sizable minority of states sanction such a reading as a means of testing the expert's qualifications and/or knowledge on a disputed issue, though the prevailing view seems to be otherwise. 6 WIGMORE $\$ 1700 \mathrm{nn}$. 2-3, and cases cited therein; Comment, 2 U.C.L.A.L. REv. 252, 254 (1955). Where the expert has specifically mentioned and relied on a medical treatise, it may be read to impeach him on the theory of discrediting a witness by demonstration of misstatement on a material point. This use is broadly recognized. W'IGMORE, supra at note 4; 29 U. CIN. L. REv. 255, 257-58 (1960). See notes \$5-36 supra and accompanying text.
} 
lawyer's closing argument to the jury. ${ }^{57}$ An alternative method frequently followed is to have the physician read the excerpt orally on direct or cross-examination before he is asked to comment on it. ${ }^{.8}$ Only rarely are the jurors requested to read the passages themselves. After the pertinent portion of the treatise is read to or for the benefit of the jury, interpretive comments will be made. As a general rule, the function of elucidation is performed by the authenticating physician. In fact, many of the lawyers questioned stated that in their experience only the expert was allowed to explain and expand on the text passage. Even where such a procedure does exist, however, a skilled advocate can and, on the basis of comments in the questionnaires, does frequently summarize the import of his treatise evidence, either implicitly or expressly, in his final argument to the jury.

Responses were divided over whether treatises introduced by the parties usually go with the jury to the jury room during deliberation, the majority replying negatively. ${ }^{59}$ As a matter of speculation, xeroxed or photographed copies made by the offering lawyer would appear to stand a better chance of being allowed in the jury room than an entire textbook, only a small excerpt of which was admitted in evidence. Most of those responding agreed that juries are usually instructed by the court to confine their consideration of any text material to those passages actually read or pointed out to them in court. Such an instruction would have importance only when the

${ }^{57} \mathrm{~A}$ few jurisdictions apparently permit counsel to read from a medical book in argument to the jury while refusing to admit the same excerpts as direct evidence. See, e.g., State v. Hoyt, 46 Conn. 330, 337-38 (1878): "[ [] n this jurisdiction for a long series of years counsel have been permitted to read to the jury as part of their argument ... extracts from such treatises as by the testimony of experts have been accepted by the profession as authority upon that subject ...." Cf. State v. Soper, 148 Mo. 217, 49 S.W. 1007 (1899) (denial of counsel's request to read medical texts to jury not error since matter is one of court's discretion). This result is achieved in a few states by accepting a tenuous differentiation between the permissible use of a text passage in argument for purposes of illustration and the impermissible use thereof as evidence. See Cory v. Silcox, 6 Ind. 39 (1854); 3 B. JONES, EvideNCE $\$ 623$ (5th ed. 1958); 6 WiGMORE $\$ 1700$. However, since this rule allows placing before the jury by indirection material which is otherwise inadmissable, most courts forbid such a reading. $3 \mathrm{~B}$. JoNEs, supra.

"s See note 24 supra and accompanying text; cf. Eagleston v. Rowley, 172 F.2d 202 (9th Cir. 1949) (non-jury, civil suit); State v. Nicolosi, 228 La. 65, 81 So. $2 d 771$ (1955). It has been held permissible for an expert witness to read from a scientific pamphlet or treatise to corroborate his testimony. E.g., Coastal Coaches, Inc. v. Ball, 234 S.W.2d 474 (Tex. Civ. App. 1950). But see 3 B. Jones, supra note 57, at $\$ 622$.

${ }^{80}$ Numerically, thirty-three questionees answered "yes" to this question, forty-two answered "no." 
entire book was taken to the jury room. ${ }^{60}$ The practice of allowing text evidence to accompany the jurors during deliberation generally increases the impact of this evidence as compared to that of expert testimony given earlier in the trial. A juror would tend to refer to the treatise or his copy of the excerpt to resolve any lingering doubts caused by a conflict between it and the opposing testimony, the details of which he may have forgotten. Thus, the treatise would have the last chance at persuading the jury to adopt "its" view.

\section{JUSTIFICATION FOR LEARNED TREATISES EXCEPTION}

The main criteria against which any proposed exception to the hearsay rule is measured are the necessity of receiving the evidence and the probability of its trustworthiness. ${ }^{61}$ In the area of medical and other learned treatises, theory and practice combine to build a strong case for sustaining an exception to the hearsay rule. The probability of truthworthiness of learned treatises has been recognized to be high. Since learned authors are writing for their profession, their published work will be subject to scrutiny and criticism of others in the profession. This factor not only promotes sound scholarship but also makes it likely that shortcomings in the published work will be exposed. Adding to this the authoritativeness of the work as a requirement for admission and the disinterestedness of the outcome of the trial, the balance is struck definitively in the direction of satisfactory reliability.

The criterion of necessity is intended to insure consideration of alternative ways for getting a particular piece of evidence admitted. One alternative to the use of text evidence is procurement of the author to testify in person. However, this alternative poses a potentially inordinate burden of cost on the litigant. In addition, if the author resides outside the jurisdiction, he may be beyond the

10 The modern practice posits in the trial judge discretion as to whether an exhibit or document admitted into evidence shall accompany the jury to the jury room. C. MCCORMICK, Evidence $\$ 184$ (1954).

O1 J. Tracy, Handbook of the Law of Evidence 229.30 (1952); 5 Wrgmore $\$ 1420$. Dean Wigmore's application of these criteria to the learned treatises area is contained in 6 WIGMORE $\$ \S 1691-92$. These criteria are merely inversions of the primary objections to juridical acceptance of hearsay declarations; i.e., as out-of-court matter typically reported second-hand, and resting for its probative value on the credibility of one not under oath or subject to cross-examination, it is fraught with unreliability; and since the declarant may ordinarily be brought into court to testify directly as to the facts asserted, admission of the hearsay is not necessary. When these objections are removed, exclusion is no longer justifiable. 
reach of legal process. Therefore, there may be no practicable way of presenting his opinion as direct evidence, other than to admit the book itself. Another avenue, that of questioning a medical expert on the content of a learned treatise, is allowable only to verify the competence of the expert and, under the majority rule, may not be used as a means to inject the treatise author's findings and conclusions.

Also tending to support the "necessity" of the learned treatise exception to the hearsay rule is the feeling of many Alabama attorneys that the operation of the rule in their state is an invaluable, if not an essential, aid in medical malpractice cases, cases in which a doctorowned insurance company is defendant, and cases involving a reluctant medical witness. ${ }^{82}$ Even in normal civil suits, it is often difficult

${ }^{02}$ It is becoming increasingly evident that changes in the law are necessary to cope with the special problems of the malpractice action. See Note, 77 HARv. L. REv. 333 (1963). Speaking of the reasons behind the original Massachusetts statute providing for direct admission of textual evidence in malpractice actions, one commentator noted: "It is well known that doctors are usually unwilling to take the witness stand in a malpractice case to give expert evidence as to the care and skill used by fellow-physicians in similar cases. As a result of this refusal by the medical profession to inform the court as to matters within their specialty when the case is one of alleged malpractice, many a victim of a physician's negligence has gone uncompensated, and other physicians are thereby also permitted to depart from the recognized standards of skill and care without the risk of accounting to the victim." 10 NACCA L.J. 256, 257 (1952).

Even if medical texts were held to be admissible as direct substantive evidence, courts would still be faced with the problem of passing on their relevance as evidence of the standard of care required of the doctor in a particular community. Under the present majority rule, the written opinions of experts may not be presented as evidence of the best or safest techniques: "It is obvious that medical books cannot fix the standard of practice for a particular community-the standard of practice for a particular community may be higher or lower or differ otherwise from the textwriter's recommended practices." Scarano v. Schnoor, 158 Cal. App. 2d 612, 620, 323 P.2d 178, 183 (1958). Even under the special Massachusetts statute allowing the introduction of books in malpractice cases, MAss. LAws ANN. ch. 233, §79C (Supp. 1966), the Massachusetts court in Ramsland v. Shaw, 341 Mass. 56, 166 N.E.2d 894 (1960), was of the opinion that the geographical referent of books used to establish the standard of care required of a doctor must be in terms of the particular locality since the standard is local: "This treatise was published in England and was written by an English author.... [T] he judge in exercising his discretion was influenced by the fact that there might be differences between the anesthesia procedures and techniques obtaining in England and those obtaining here. The defendants' conduct, of course, must be tested by the standards of care and skill prevailing in the community where thcy practised." Id. at 64-65, 166 N.E.2d at 901. See also Reddington v. Clayman, 334 Mass. 244, 134 N.E.2d 920 (1956), for an example of the difficulties besetting the attorney in his attempt to establish the fact that the author is expert in his profession in a malpractice suit.

Under the Nevada statute, NEv. REv. STAT. $\$ 51.040$ (1965), however, which is similar to the Massachusetts statute, the supreme court of that state has recently indicated that, upon establishment of the expertise of the author, his writings will be admissible in malpractice cases if he was familiar with standards of practice throughout 
in the smaller communities to get a live witness to testify because of expense, travel, and inconvenience. Thus, the need for and advantages of educating the jury on the question at hand may render resort to publications imperative.

\section{The Objections to a Learned Treatises Exception}

An analysis of the aggregate experience of Alabama trial lawyers under the Williamson rule aids in evaluating the substance of recurring objections to its adoption elsewhere. The major reason articulated for disallowing the use of learned treatises as direct evidence is that it violates the rule against hearsay evidence. ${ }^{63}$ This is doubtless true, for the author of the submitted statements is not present for cross-examination and he did not originally make the statements under oath. The efficacy of the oath in securing reliable testimony is open to question. ${ }^{64}$ Also, the reliability of the treatise is assured by the author's desire to avoid criticism of it by his peers. ${ }^{65}$ In addition to the hearsay rationale, courts have ascribed several other reasons for excluding learned treatises as independent evidence: medicine is not an exact, but a changing science; ${ }^{66}$ the author's thesis may not be fairly and accurately represented; ${ }^{67}$ the opinions of authors on the same subject may differ radically; ${ }^{68}$ and juries are unable to understand the technical language of scientific treatises. ${ }^{68}$ The viability of each of these objections and of the demand for cross-examination will be evaluated in light of the Alabama experience.

The theory supporting cross-examination of experts is that it helps to establish the accuracy of their assertions and tests their quali-

the United States, even though he was not familiar with the standard in the locality. See Foreman v. Ver Brugghen, 81 Nev. 86, 398 P.2d 993 (1965) (dictum).

oa E.g., Baily v. Kreutzmann, 141 Cal. 519, 75 P. 104 (1904); Hallworth v. Republic Steel Corp., 153 Ohio St. 349, 91 N.E.2d 690 (1950).

of Writing of the inefficacy of the oath in judicial proceedings, Bentham has commented: "But, whether principle or experience be regarded, it will be found, in the hands of justice an altogether useless instrument; in the hands of injustice, a deplorably serviceable one." 1 J. Bentham, Rationale of Judicial Evidence 366 (1827).

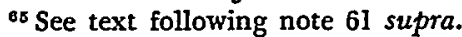

${ }^{\circ}$ Cf. Goldthwaite v. Sheraton Restaurant, I54 Me. 214, 145 A.2d 362 (1958).

${ }^{67}$ See Boyle v. State, 57 Wis. 472, 15 N.W. 827 (1883).

os Bixby v. Omaha \& C.B. Ry. \& Bridge Co., 105 Iowa 293, 75 N.W. 182 (1898).

${ }^{\circ}$ Bowles v. Bourdon, 148 Tex. 1, 219 S.W.2d 779 (1949). 
fications. ${ }^{70}$ However, when the accuracy and competency of the expert is unquestioned by the particular profession, ${ }^{71}$ the need for cross-examination is questionable. Thus, the need to "cross-examine" the content of a widely-respected medical treatise would appear to be minimal. Indèed, instead of "cross-examining" the treatise, the opponent of the party introducing the treatise could refute the treatise's evidence more effectively by presenting his own authority, in the form of another accepted treatise or a qualified live expert witness. However, the logic of these conclusions is apparently not recognized by supporters of the majority rule, who argue that the inability to "cross-examine" treatises should preclude their use as direct evidence.

Furthermore, the necessity of cross-examination to test whether a witness meets the minimum qualifications of an expert ${ }^{72}$ is lessened by the fact that the author of a treatise generally will be more qualified than the average acceptable witness. No live expert witness is ever totally disinterested, if only because of the fee he receives..$^{73}$ In addition, some expert witnesses are simply biased. ${ }^{74}$ Thirdly, the "conspiracy of silence" among doctors forecloses much expert testimony. ${ }^{75}$ To the extent these conditions exist, the quality of the evidence elicited from expert witnesses is diluted. The scholarly publication, on the other hand, is certainly disinterested in the outcome of any particular trial. Furthermore, since scholarly publications are presumably written for the purpose of disseminating knowledge, it is reasonable to assume that the author, if he is recognized in his field, has accurately presented the matters with which he deals.

${ }^{70}$ Moore v. State, 184 Ark. 682, 43 S.W.2d 228 (1931); Van Stike v. Potter, 53 Neb. 28, 73 N.W. 295 (1897).

71 The legal requirement of authentication, which must be met in Alabama before admission of a learned treatise as evidence is allowed, would insure that the author is considered an authority in his profession. See notes 16-18 supre and accompanying text; text following note 48 supra.

72 The requirement that the author of the text be an authority in the field is part of the minority rule. See City of Dothan v. Hardy, 237 Ala. 608, 607, 188 So. 264, 266 (1939).

7 Bomar, The Compensation of Expert Witnesses, 2 LAW \& ConTEMr. ProB. 510, 522 (1935).

"People v. Vanderhoof, 71 Mich. 158, 168, 39 N.W. 28, 32 (1888); see Elliott \& Spillman, Medical Testimony in Personal Injury Cases, 2 LAw \& CoNIEMP. ProB. 466 (1935).

${ }_{75}$ Brown v. Keaveny, 326 F.2d 660, 661 (D.C. Cir. 1963) (Wright, J., dissenting); Huffman v. Lindquist, 37 Cal. 2d 465, 483, 234 P.2d 34, 45 (1951). 
Medicine is a changing science

A second objection to the rule permitting use of medical treatises is the observation that medicine is a highly inexact and changing science, and that medical books consequently tend to be outdated and unreliable. ${ }^{76}$ To this criticism the overwhelming majority of those questioned were unsympathetic. Initially, Alabama practitioners urged that such an objection goes to the weight of the evidence, not to the question of admissibility. To the substance of the objection, they argued that in order for the treatise to be admitted under Alabama law, it must be shown by competent evidence to be a standard authoritative text. ${ }^{77}$ If the book were proved to be outdated, - it would presumably not be considered standard and authoritative. Secondly, it was felt that a lawyer would be foolish to attempt to use an outdated publication because, even were it to be admitted, its probative weight could be easily discounted by proof of a later publication. Finally, many felt that, even though only a relatively small volume of the material in standard medical texts is outdated, it is precisely because medicine is a changing science that books should be admitted. The thrust of this argument is that the majority of doctors, who become the expert witnesses at trial, are reluctant to abandon theories learned in medical school, that they often fail to keep up with medical advances, and that many know very little about laboratory techniques, the meaning of laboratory data, and record-keeping procedures. This general attitude reflects the feeling that if medical evidence is to be admitted at all, it should not be confined to expert witness testimony, but should comprise all relevant and authoritative expert opinion, with the determination of the weight to be afforded the evidence left to the triers of fact.

\section{Inaccurate or misleading presentation}

The present majority rule is frequently justified on the ground that it precludes the problem of misleading or inaccurate representation of the author's views through presentation of passages isolated from their context. Insofar as this objection is intended to indicate a condition unique to evidence in published form, it is specious. Even live expert testimony is subject to an unfair presentation by

\footnotetext{
${ }^{76}$ Goldthwaite v. Sheraton Restaurant, 154 Me. 214, 145 A.2d 362 (1958).

${ }^{77}$ E.g., Stoudenmeier v. Williamson, 29 Ala. 558, 567 (1857).
} 
virtue of what is or is not disclosed, ${ }^{78}$ yet the adversary system is deemed a sufficient safeguard for eliciting truth and impeaching the credibility of experts who do not give accurate testimony. Similarly, in the case of published writings offered in evidence, the opposing counsel may be relied upon to detect the quality of evidence and, if it is false or misleading, to expose these defects. ${ }^{79}$

\section{"Battle of the books"}

Another objection to a learned treatises exception to the hearsay rule is that, in cases involving debated medical issues, the opinions of authors may differ radically concerning a particular issue. ${ }^{80}$ Thus, each side may attempt to overwhelm the other with the sheer number of authorities supporting its claim. This possibility could occur in Alabama, for the vast majority of the questioned attorneys reported that trial judges do not limit the number of medical treatises which can be introduced by each side. ${ }^{81}$ Presumably the Alabama courts have not invoked their discretion to impose any limits because no deluge of treatises has occurred. The results of the questionnaire confirm this conclusion. The average number of medical treatises introduced in a trial in which such material is placed in evidence was reported to be between two and three for both sides, and between one and two for one side. The maximum number of books reported to have been introduced in evidence in any one trial by both sides was thirty, eighteen being the second largest figure. The maximum number introduced in one trial by a single side was twenty-eight, the next greatest number being fifteen. In addition, because juries accord more weight to the testimony of live expert witnesses than to

\footnotetext{
${ }^{78}$ Townsend v. Sain, 372 U.S. 293, 302 (1963).

${ }^{70}$ The misleading presentation objection also comprehends the situation in which an author has changed his view since the last publication date. In such a case ad. mission of the book in evidence would clearly be undesirable. Again, however, the nature of the adversary system would seem to provide a sufficient safeguard for disclosure of that fact. The only problem here is the policy choice of whether such a burden, if it is a burden, should be imposed on opposing counsel.

${ }^{80}$ Bixby v. Omaha \& C.B. Ry. \& Bridge Co., 105 Iowa 293,75 N.W. 182 (1898). As well as worrying about the disagreement among authorities, some courts have suggested that potentially time-consuming collateral proceedings may be necessary to authenticate the books offered. Hallworth v. Republic Steel Corp., 153 Ohio St. 349, 355, 91 N.E.2d $690,693(1950)$.

${ }^{81}$ A few attorneys answered that they had seen a numerical limitation imposed by the court on the number of books which could be introduced. In such cases most said the number was variable from case to case. Only three attorneys said the numerical limitation was approximately the same from case to case, that being one or two books.
} 
medical texts, the Alabama attorneys reported that (I) when one side uses a live expert witness, the other side is virtually never content to respond with a treatise alone; and (2) when one side offers in evidence a medical text, the other side does not feel compelled to respond with one or more treatises in return.

\section{The jury cannot understand}

Finally, the proponents of the present rule point out that the language of scientific treatises is unavoidably beyond the understanding of the layman. ${ }^{82}$ Hence, they conclude, the publication will only confuse the jury and, thus, be useless as direct evidence. This theory, however, is not entirely corroborated by practice. According to the majority of those questioned, if the subject matter of the treatise is sufficiently technical to be beyond the comprehension of laymen, then some kind of interpretation will be provided to the jury, in addition to the passage being read to them. ${ }^{83}$ This interpretation is most often provided by an expert witness on direct or cross-examination, or by the lawyer in his argument. ${ }^{84}$ Furthermore, a substantial number of attorneys felt that in many cases where such evidence was involved the jury could easily understand the medical excerpt without any interpretation. If the meaning of the passage could not be conveyed to the jury with a simple explanatory statement, some lawyers would simply not use the book. Thus, the sentiment again was that such criticism does not go to the admissibility of the learned treatise, but only to its weight. In addition, several of the trial attorneys indiated that this issue involved more basic considerations, namely, that the real question is whether juries are qualified to judge expert testimony from any source, live or published. However, so long as the jury system is employed, the assumption must be that they are so qualified, and, therefore, any rule which restricts the jury from being exposed to all relevant expert testimony is undesirable.

\section{ConcLusion}

The questions posed at the outset concerned the workability of the Alabama learned treatises exception and its qualitative impact upon the trial process in that state. Several evaluative conclusions

\footnotetext{
${ }^{82}$ Bowles v. Bourdon, 148 Tex. 1, 7, 219 S.W.2d 779, 783 (1949).

${ }^{83}$ The Williamson court indicated that such interpretive comment was required in an instance such as this. $29 \mathrm{Ala}$, at 567 .

si See text following note 58 supra.
} 
suggest themselves upon an analysis of the questionnaire results. First, it is apparent that the Williamson rule is not widely known or appreciated by the trial bar in that state. ${ }^{85}$ This unfamiliarity may be inferred from the low number of returned questionnaires, ${ }^{86}$ the assumption being that a completed questionnaire is, to a measurable degree, a function of the respondent's experience with the rule. Further, even of those who did respond, a sizable number commented that the rule is rarely invoked or that they were not aware that such a rule existed. Also disclosed was the misconception held by a significant number of the responding attorneys that learned treatises are only competent to impeach or test a witness on cross-examination. The Williamson rule, of course, relates only to the introduction of learned treatises as direct, independent evidence.

Secondly, the segment of trial attorneys sampled by the questionnaire overwhelmingly approved of the learned treatise exception. ${ }^{87}$ This approval seemingly reflects the general opinion of Alabama attorneys knowledgeable as to its operation, again on the assumption that the questionnaires remitted came primarily from attorneys who are most familiar with or who have marked feelings concerning the exception. Nonetheless, it is apparent that trials in Alabama have by no means been drastically changed by the availability of medical books as direct evidence. Instead, these materials have played a secondary, though valued, role. A medical text is most often used as an adjunct to live expert testimony, serving to augment the probative force of such evidence or to cast doubt upon the medical conclusions urged by the other side. In instances in which a party cannot secure the services of a physician as a witness, as is not uncommon for plaintiffs in medical malpractice actions, the fact that medical books may be employed at least assures that

${ }^{85}$ This observation is not intended as a criticism of the Alabama bar. The facts that the Williamson doctrine is quite old and that it has not been the topic of recent discussion or pubhicity within the state's legal community may explain its relative obscurity. Since, in connection with this project, almost all attorneys in the state were sent a letter explaining the rule and its operation, an expanded usage might be anticipated in the future.

${ }^{80}$ The ratio of questionnaires sent to those received was approximately 6 percent. See note 7 supra. This figure is misleading, though, since no distinction was made between "trial" and "non-trial" lawyers in the circularization, no list of the former alone being available, and only those with litigation experience were expected to reply.

${ }^{87}$ Only nine attorneys indicated that they personally disapproved of the exception, and of this number three, while agreeing in principle, desired some minor modification in the details of its operation. 
the suit will not be prematurely terminated. This result alone may be regarded as sufficient to justify a learned treatise exception to the hearsay rule.

The use of medical books at trial has also a more subtle influence in "keeping the game honest."88 A witness may testify as an expert in Alabama if he is shown in preliminary proof to have any knowledge of his subject beyond that of the average layman. ${ }^{89}$ Serious deficiencies in his comprehension can often be most graphically demonstrated by use of a treatise. Several attorneys emphasized the "deterrence" value of treatises; i.e., the mere sight of a stack of books on medicine, they find, provides an incentive to the testifying doctor to observe high standards of accuracy. Thus the mere threat of the introduction of a book to expose dishonest or biased testimony is often sufficient to make its actual use unnecessary. Even aside from the problem of opinionated testimony, the Williamson rule may elevate the qualitative level of medical evidence by facilitating the presentation of new developments and advances, about which the general community of practicing physicians may not be fully aware. In all, there is detectable a generalized undercurrent of sentiment among the responding attorneys that medical texts provide a very beneficial countervailing force to expert testimony and serve to keep the latter from completely dominating a case and its outcome.

Though the Williamson rule is serviceable in its present form, several recommended improvements merit consideration. For reasons already discussed, ${ }^{90}$ provision should be made to require that advance notice be given opposing counsel concerning the intended use of specified treatises, with full disclosure of title, author, and date of publication. This procedure would tend to discourage resort to materials of questionable repute, too many of which have been admitted according to the complaints of several of those questioned. The suggestion was made by one attorney that treatises be allowed to be authenticated by the ex parte affidavit of a physician. The obvious benefit of such a proposal lies in the opportunity it affords

\footnotetext{
${ }^{88}$ An attitude of mistrust of the integrity of medical witnesses was surprisingly prevalent throughout the questionnaires.

${ }^{89}$ See, e.g., Thompson v. Magic City Trucking Serv., 275 Ala. 291, 295, 154 So. 2d 306, 310 (1963); cf. Alabama Consol. Coal \& lron Co. v. Heald, 168 Ala. 626, 643, 53 So. 162,167 (1910).

See text accompanying notes $54-55$ supra.
} 
to by-pass testimonial authentication by a physician in court, with its attendant expense. However, this change does not seem desirable in light of the charge that some Alabama courts have been too lax in receiving published materials of questionable quality and of the need to retain an occasion for challenging the authoritativeness of proffered texts. An alternative suggestion is to expand the role of judicial notice in this same authentication area. Thus, those medical texts which are repeatedly brought into court and successfully authenticated by various attorneys might be received without the necessity of formal proof of their status as standard works. The drawback of this procedure is that a book, once recognized as standard by judicial notice, would tend by the natural inertia of the system to retain this "privileged" status long past the day it represents current and accurate medical opinion. The anticipated loss of flexibility in the trial judge's control over admissibility argues against such a procedure.

The purpose which these last two proposals are designed to effect could perhaps best be achieved by adoption of a pre-trial request-foradmission procedure patterned after that of rule 36 of the Federal Rules of Civil Procedure.91 This procedural mechanism would reduce the number of instances in which in-court authentication must be executed, while at the same time it would preserve to opposing counsel the opportunity to contest this issue, should he deem it advisable to do so. ${ }^{92}$

Finally, although the majority of attorneys reported that the jury was not allowed to take the learned treatises which had been admitted as evidence with them to the jury room, many thought that the rule would be improved if duplicated copies of the material which had been introduced, rather than the entire treatise, were allowed to

91 FED. R. Crv. P. 36. This rule authorizes a party to serve a written request for the admission of the genuineness of a relevant document or truth of a relevant fact upon the other party. The matters submitted are regarded as admitted if the latter does not respond with a specific denial, a statement explaining why he cannot admit or deny them, or an objection based on privilege, irrelevance, or impropriety. If, after receiving a denial of the matter concerning which an admission was sought, a party proves the same, he may apply to the court for an order to the other party to pay the expenses incurred in effecting such proof. FED, R. Civ. P. 37 (c). The authoritativeness of a text is sufficiently akin to the "genuineness of a document" for rule 36 to serve usefully as a vehicle for adoption and adaptation to achieve pre-trial authentication.

02 Even with the adoption of a viable method of pre-trial authentication of medical books, most attorneys may be expected to continue to meet this condition of admis. sibility by testimony of a doctor, whose appearance as a witness is generally deemed necessary because of other considerations. See text accompanying notes $41-42$ supra. 
accompany the jury during deliberation. However, since oral testimony, for which the admission of a learned treatise is only a substitute, is not generally admitted to the jury room, ${ }^{93}$ there is little reason why such an exception should be made. Indeed, to permit such evidence to be taken to the jury room would unreasonably elevate its influence over that of other testimony. ${ }^{04}$

\section{APPENDIX}

\section{QUESTIONNAIRE}

INSTRUCTIONS:

Please answer all the questions; if you feel, however, that you cannot fairly answer a question, mark it CANNOT ANSWER and state any reasons for this response which you think might be helpful to us. In a few instances, more than one of the suggested answers may be true, in which case you may check as many as are appropriate. We solicit your explanatory comments on any and all questions, particularly if the specified answers are not meaningful to you or an important alternative has been omitted. Please feel free to use the back of these sheets if the space provided is not adequate for your comments and answers. Since our major concern is with the use of medical treatises under the learned treatise rule, most of the questions have been phrased in terms dealing with the medical treatise. If, however, there is a significant difference in treatment observed by you as to other, non-medical learned treatises, please comment to this effect under the appropriate questions. The completed questionnaire should be returned to: DUKE LAW JOURNAL, DUKE UNIVERSITY, DURHAM, NORTH CAROLINA.

1. What is the size of your law firm? partners and associates

2. How long have you been practicing law in Alabama? more than 30 years between 20 and 30 years between 10 and 20 years less than 10 years

3. During that time in how many civil and criminal cases do you estimate that you have participated as a trial advocate in both state and federal courts? more than 500 cases between 100 and 500 cases

\footnotetext{
${ }^{93}$ See, e.g., Zank v. West Penn. Power Co., 169 Pa. Super. 164, 82 A.2d 554 (1957); Model Code of Evidence rule 105, comment m (1942).

- See Tescon, Should Impeaching Documents Go to the Jury?, 1959 TRIAL LAwYER's GuIDE 311, 317.
} 
between 20 and 100 cases

fewer than 20 cases

4. Do you consider that you are now or have been at some time a specialist in the trial of cases, either civil or criminal?

$$
\text { Yes }
$$

5. What percentage of your trial experience has been in criminal cases civil cases

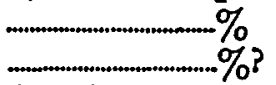

6. In criminal trials, in what percentage of the cases have you represented

the prosecution the defense

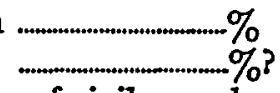

7. In what percentage of civil cases have you represented the plaintiff the defense

8. In how many medical malpractice cases have you represented the plaintiff the defense

9. In what number of the civil cases which you have tried have medical issues been involved? most cases a considerable number of cases few or no cases

10. In what number of the criminal cases which you have tried have medical issues been involved? most cases

...n.......................... a considerable number of cases few or no cases

11. On approximately how many occasions have you offered in evidence, in order to prove their truth (not just for impeachment purposes), assertions made in learned treatises or text books?

$$
\text { (number) }
$$

12. How many of the occasions specified in the preceding question have involved medical books?

$$
\text { (number) }
$$

[If a numerical answer in the following three questions is not possible, reasonably accurate percentage figures will be acceptable.]

13. On how many occasions have your proffered excerpts from medical books been admitted into evidence by the trial judge?

$$
\text { (number) }
$$

14. When such offers of evidence have been rejected by the trial court, in how many cases has it been on the grounds of

$$
\text { relevance (including remoteness, prejudice) }
$$

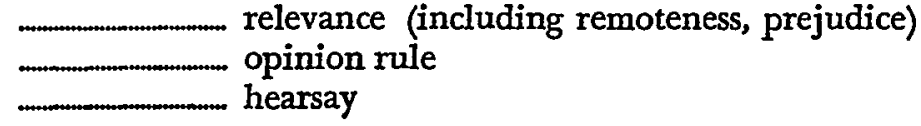


insufficient authentication

other. grounds (please specify):

15. In how many cases have you successfully authenticated medical treatises (shown them to be recognized authorities)

by testimony on direct examination of your medical expert (including your client if he was a physician) by testimony on cross-examination of your opponent's medical expert (including his client, if a physician)

by persuading the court to take judicial notice of authenticity

by testimony of a medical librarian

by other means (please specify):

16. From your observations are medical treatises more likely to be admitted when offered

in criminal cases, by in medical malpractice in other civil

\section{................. the prosecution the defense no difference} cases, by

............. the plaintiff
cases, by the plaintiff

17. Among those learned treatises from which you have successfully introduced statements of fact or opinion as evidence of the truth of such statements are the following (please give names of books and authors):

18. List which of those treatises, if any, the trial judge has admitted without requiring specific authentication (by taking judical notice that they are standard or recognized authorities) (names of books and authors):

19. Among the types of learned treatise materials which you have successfully offered into evidence are the following: books pamphlets, such as:

periodicals, such as:

other materials, such as:

20. In your experience have trial judges required advance notice to the 
other side if medical treatises are to be offered in evidence? Yes No

21. In your experience lawyers have given such advance notice in actual practice: almost always frequently seldom, if ever.

22. Do trial judges usually limit the number of medical treatises which can be introduced by each side? Yes No

23. Such a numerical limitation, where imposed, has been variable from case to case approximately the same from case to case.

24. If you marked the latter alternative in the preceding question, what has the numerical limitation, i.e., the greatest number of medical treatises which may be introduced into evidence, typically been? treatises per side

25. What is the greatest number of medical treatises which you have seen introduced in a single trial?

by both sides

by one side

26. What is the usual or average number of medical treatises introduced in a trial in which some such material is placed in evidence? by both sides by one side

27. When one side offers into evidence a medical treatise, the other side responds with one or more treatises in return:

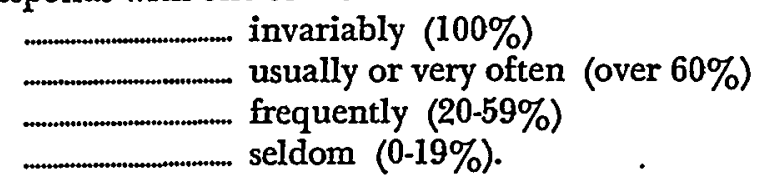

28. When one side uses a live expert witness, the other side is content to respond with a treatise alone in most cases frequently seldom.

29. Excerpts from medical treatises are usualiy presented to the jury by: asking the jurors to read the passages themselves

hary
having the lawyer read the passages to the jury
by other methods (please specify):


30. Do the treatises introduced by the parties usually go with the jury to the jury room during deliberation? Yes No

31. Are juries usually instructed by the court to confine their consideration of any treatises to those passages actually read or pointed out to them in court?

Yes No

32. Are passages from medical and other technical books usually "interpreted" to the jury in addition to being read or pointed out to them? Yes No

33. This interpretation is required to be given by an expert witness is usually provided by an expert witness, though other methods of presentation are allowed may be provided by the lawyers is sometimes provided in other ways (please specify):

34. From your observations, what effect do passages from learned treatives introduced without interpretation have on a jury (e.g., apt to confuse jury, usually understood by jury, etc.):

35. In your opinion, do juries give appreciable weight to learned treatises evidence?

Yes No

36. Do you think that texts of psychiatry are given the same weight by juries as other medical treatises?

$$
\text { Yes } \quad \text {.................................... No }
$$

37. What are your comments as to the validity of the criticism, frequently raised against the admission of medical treatises, that medicine is an inexact and rapidly changing science with resultant large numbers of frequently contradictory and outdated books which a jury should not be required to compare and evaluate as evidence?

38. Where a passage from a book conflicts with an opinion expressed from the stand by an expert witness, the jury

will more often than not accept the opinion of the live witness

will more often than not accept the statement from the written authority

will accept one or the other rather unpredictably.

39. Where the live witness and the conflicting book are of substantially equal merit and authority, presentation by means of the live witness is more effective 
in nearly all instances

in most instances

in some instances

in few instances

40. Excluding any intrinsic superiority of a live witness over a written authority (or vice-versa) as alternative means of introducing evidence, what factors offset or accentuate the relative persuasiveness of the two kinds of evidence (e.g., authority of witness or textbook author, method of presenting treatise, etc.)?

41. Please comment on the impact, if any, of the following or any other contextual circumstances on your decision as to whether to establish a medical fact by use of a hive expert witness or by use of a medical treatise.

the difficulty of the medical issue:

the identity of the finder of fact, i.e., judge or jury:

the sex and/or race of your client (or of the opposing client):

the type of court, i.e., state or federal:

the nature of the case, i.e., criminal or civil, medical malpractice, etc:

the side of the case you represent, i.e., plaintiff or defendant, prosecution or defense:

other:

42. Have you found it generally more or. less troublesome and/or expensive to produce a witness to authenticate a medical treatise than to procure an expert witness to prove by oral testimony what otherwise might be proved by use of a treatise? more troublesome and/or expensive less troublesome and/or expensive

43. To abolish the learned treatise rule in Alabama would alter the dayto-day practice in

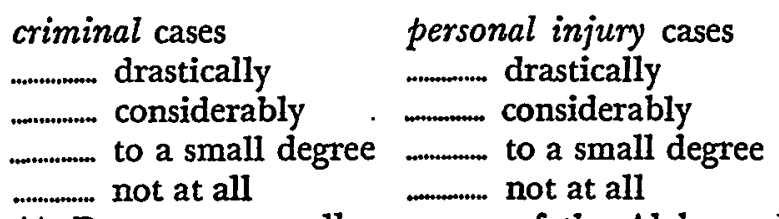
medical malpractice cases

............... drastically considerably to a small degree not at all.

44. Do you personally approve of the Alabama learned treatise rule of evidence?

Please comment on the reasons for your answer. 
45. In what respect (s), if any, could this Alabama evidence rule be improved:

46. Any observations you wish to add will be appreciated. We especially solicit any further comments you may have on the practical application of the learned treatise rule in Alabama or on any areas which this questionnaire neglects. 